\title{
Turkey's aborted attempt at export-led growth strategy: Anatomy of the 1970 economic reform
}

\section{Ali Tekin}

To cite this article: Ali Tekin (2006) Turkey's aborted attempt at export-led growth strategy: Anatomy of the 1970 economic reform, Middle Eastern Studies, 42:1, 133-163, DOI: $10.1080 / 00263200500261902$

To link to this article: https://doi.org/10.1080/00263200500261902

Published online: 08 Aug 2006.

Submit your article to this journal 전

Џlll Article views: 152 


\title{
Turkey's Aborted Attempt at Export-Led Growth Strategy: Anatomy of the 1970 Economic Reform
}

\author{
ALI TEKIN
}

Turkish economic history is full of ups and downs. Although mired with financial crises in the 1990s and early 2000s, its economic problems generally stemmed from foreign exchange shortages. Adopting an import substituting industrialization strategy in most of the post-World War II period, the country, like its counterparts in Latin America, was immersed into an economic environment with unsustainable foreign account deficits. This major constraint on the fortunes of the Turkish economy disappeared in the early 1980s when the Turkish government asked Turgut Özal, a powerful technocrat at that time, to design and implement a wideranging economic reform package. The reform measures, announced on 24 January 1980, were not fundamentally different from those initiated earlier in 1958 and 1970. Yet, this time, contrary to the previous episodes, the reform measures remained in place and relegated Turkey's foreign exchange problem to the shelves of economic history.

There are ample accounts of the 1980 Turkish economic reform programme. ${ }^{1}$ What is missing from the literature, however, is a full account of the earlier economic reform episodes in 1958 and 1970, especially with a view to interpreting why these reform measures had been reversed within a few years after their introduction. This void is even more significant for the 1970 reform episode in the face of strong evidence that the initial response of the economy to the reform measures was spectacular. Despite the better than expected initial outcome, the 1970 reform package was gradually abandoned by the government(s) - marking the beginning of the economic and political 'dark age' of Turkey in the second half of the 1970s. This article attempts to analyse the dynamics of the 1970 Turkish economic (trade) reform episode with the aim of interpreting why it was abandoned by the mid-1970s.

Decades of import substitution policies in Turkey, although occasionally interrupted, had resulted in a political economy in which profits were made by manipulating behaviour rather than production for the market (domestic or international). State intervention generated economic rents, and economic interest groups attempted to maximize their shares both by influencing state policies and by competing with one another. Areas of conflict and congruence among the interest groups during the 1970s included issues of foreign trade: exchange rate policy, import protectionism, and the foreign exchange supply. ${ }^{2}$ 
Both the private and public sector groups were divided deeply among themselves over the assessment of foreign trade policy problems and their solutions. There were divisions between inward-looking policy interests and outward-looking policy interests as well as differences among the actors within each policy camp. The inward-looking interests were voiced by import substituting private industrialists, importers, and the State Economic Enterprises (SEEs) and institutions with import and industry related duties. Their interests generally converged on overvalued exchange rates, high import barriers, and de-emphasis of export promotion. On the other side of the spectrum, outward-oriented interests were voiced by exporters, the producers of exportables (mainly agriculture), tourism sector, Turkish workers in Western Europe, export-related departments within the state structure, and international financial creditors. Their interests converged on realistic or undervalued exchange rates, liberal import regime, and promotion of exports. In the following pages, this study provides a detailed assessment of these factors within competing foreign trade policy coalitions, and their interests.

Within such a context, the 1970 reform process started out with balance of payments difficulties. This led to the ascendancy of pro-reform (pro-trade) policymakers within the state apparatus. The rise of pro-traders to key positions made it possible to undertake reforms, and facilitated policy dialogue with the international creditors, who held the resources, the transfer of which was vital to short term relief from the foreign exchange shortage.

The point when foreign exchange became relatively abundant seemed to be the defining moment for the fate of the reform. Since the core reason for the 1970 reform was the balance of payments difficulties in the first place, the protectionist groups began, at this juncture, to campaign that the reform measures be discarded. These groups were still stronger at that point (both economically and politically) than the pro-trade coalition, and they had the potential to dominate the economic realm as soon as the pro-trade policymakers lost their vigour.

There were no strong signs of pro-trade private sector pressures on the policymakers during the initiation and the implementation stages of the reform. Also, the reformers did not approach the pro-trade sector groups. It was quite apparent that the reformers did not provide leadership to build a coalition of export interests following the announcement of the reform. In addition, the pro-reform circles' policy dialogues with the international donors were rather weak. These factors were critical for the eventual fate of the 1970 measures, as technocrats with protectionist sentiments and their private sector allies were able to sideline the proreform elements in the policymaking domain quite easily.

The protectionist coalition advanced the idea that the inward-orientation was fundamentally 'correct' for Turkey, and since its short-term foreign exchange shortage had been overcome, the country should have continued its efforts in 'national' industrialization. These protectionist ideas became dominant, and the end result was the reversal of the 1970 reform within several years of its inception.

There was always the possibility of an alternative path. If the reformers had early on built a policy coalition with the pro-trade private sector groups and international creditors, they could have improved the likelihood of the sustainment of the reform. In this case, as the balance of payments situation improved in the post-reform period, the protectionist pressures would not necessarily result in the reversal of the 
reform since there would have been a strong coalition of pro-trade groups that could have neutralized the protectionist pressures. This alternative possibility was adopted not in the case of the 1970 reform, but only ten years later in 1980.

This study first deals with the political economy of Turkish economic (trade) policy in the late 1960 s before proceeding to analyse the initiation, implementation and reversal of the 1970 reform.

By the time the First Five Year Plan (FFYP) went into effect in 1963, the Democratic Party's haphazard style of import substitution, and the legacy of the mid-1950s, was replaced by the import substitution in a macro, comprehensive planning framework. The FFYP stated clearly that although its main principle was to benefit from the international division of labour to the greatest extent, Turkey, as a developing country, would not have determined its industrialization and trade policies on the basis of the comparative cost structure of its economy. Instead, the comparative cost structures of the sectors were to be viewed with a long term perspective. In other words, the FFYP acknowledged that investment in the sectors with no competitive edge would be undertaken, which would be protected by foreign trade policy measures until these sectors gained the strength to compete internationally. The FFYP stated that one of its goals was to deepen the import substitution efforts as much as possible. ${ }^{3}$

Clearly, the planners dismissed an export-oriented foreign trade strategy on the basis of the pessimism on the export sectors' growth potential and their long term reliability as the source of foreign exchange. They reasoned that growth through agricultural exports would have required a substantial overhaul of the agricultural sector, which was no easy task, and did not constitute a long term solution to the country's growing employment problems. The State Planning Organization (SPO), since its inception in 1960, reasoned that Turkey's agricultural exports had low elasticity, limiting its potential as the engine of growth. The SPO also considered the manufacturing sector to be too small and too weak to lead an export drive, again dismissing any variation of an outward-oriented trade strategy. For example, B. Tuncer, one of the early directors of the Economic Planning Office of the SPO, acknowledged that 'the development plans were based on the belief that the manufacturing sector's export potential was non-existent and, even if production were to be increased, great difficulties would be encountered in trying to market the products abroad'. ${ }^{4}$ Hence pessimism about the growth of Turkish exports dominated economic policymaking towards the mid-1960s. These policy trends continued with the Second Five Year Plan (SFYP) covering the 1968-1972 period.

Both plans emphasized import substitution in the manufacturing sector. Aiming at the protection of the manufacturing sector from outside competition, foreign trade policy perspective of both of the plans consisted of the overvalued exchange rate and increasingly restrictive import policies. The plans mentioned the need to increase exports, but they did not contain the necessary measures to reach that goal.

The devaluation of the 1958 reform adjusted the exchange rate at a new, fixed rate, which was officially unified at TL9 per dollar in August 1960. Between 1960 and 1970, the official exchange rate remained at that parity. Although the inflationary trends of the 1960 were not as strong as those of the 1950s, they did result in substantial overvaluation of the TL over the years. From 1958 to the first month of 
1968, the wholesale price index rose by 72.6 per cent while the price indices in Turkey's important trade partners increased in the range of 6 to 23 per cent during the same period. ${ }^{5}$ The result of this inflation differential was the overvaluation of the TL throughout the second half of the 1960s.

In orienting the economy towards import substitution, import policy was also significant. The overvalued exchange rate gave a strong incentive to import, which needed to be kept in check with limited availability of foreign exchange. The protectionist policymakers, especially the SPO, aimed at limiting the import of consumer goods while offering incentives for capital goods to increase investment, which naturally went into the ventures producing for the protected domestic market. Another goal of the import policy was to limit the amount of intermediate goods imports to encourage investment in these sectors. ${ }^{6}$

These goals were to be achieved through the import regime, the outline of which was inherited from the 1950s. ${ }^{7}$ The regime in the 1960s consisted of two main lists (the liberalized list and the quota list) and two minor lists (self-financed imports and bilateral agreement imports). The liberalized list referred to indispensable consumer items such as medicine and to items necessary for the realization of the Plans, which were not domestically produced. The quota list included the permitted imported amounts of commodities of which domestic production was not enough to cover the total demand. In addition, there were two more import categories covering selffinanced imports and bilateral agreement imports. The first category generally regarded the capital goods imports of the public sector under the project aid agreements. The latter category listed the items importable from the countries Turkey had a bilateral agreement with. However, this type of import was required to be appear on either the liberalized list or the quota list. As a more general restriction, if a commodity was not included on any of these lists, its import was prohibited. ${ }^{8}$

The hallmark of the import policy during the second half of the 1960s was increased protectionism. Although the complexity of the import lists made the assessment of the evolution of the import regime difficult, ${ }^{9}$ it was possible to observe a few strong trends in the import regime. Looking at the data for 1962, 1965 and 1968, A. Krueger concludes that 'the gradual shift toward Quota List (as domestic production began) and the "Prohibited List" (as domestic production was deemed adequate to meet domestic demand) is evident. ${ }^{10}$ Thus, the Liberalized List imports were becoming less significant. In addition, there were 'several other factors that reduced the degree of freedom associated with Liberalized List imports. ${ }^{11}$ She also concludes that 'the shift in eligible imports away from finished consumer goods toward raw materials, intermediate goods and capital goods is apparent', ${ }^{12}$ which is another sign of increased emphasis on import substitution. Whereas the import policy gradually became more complex and required the constant attention of the policymakers, the export policy measures remained rather simple and docile.

As indicated earlier, the export regime of the 1960s was based on pessimism about the growth potential of exports. During the period, the bias of the trade regime against exports was partly the result of deliberate government policies. The export regime was in principle based on exporting without restriction. However, the practices of price registration, and licensing for certain commodities in effect discouraged export activities. Registered prices served as minimum prices at which the government permitted the export of a particular commodity. Licensing by the 
Ministry of Trade was required for some commodities from time to time depending on the domestic and international demand conditions. These commodities were important for domestic consumption as well as for exports, such as cereals, several metals, and margarine. ${ }^{13}$

During the 1960s, export subsidies became an issue of debate. The most important export subsidy was tax rebate to exporters. The FFYP stated that there was a need for a system which would reimburse exporters for the indirect taxes paid earlier on the production of export goods. The system specified the types of taxes to be reimbursed and the types of export goods that would benefit. The Cabinet decided to set up a commission in 1964 to implement the tax rebate system. The second type of export subsidy offered to exporters was the exemption of export goods from various customs taxes. The third type gave exporters access to credits at lower interest rates than others. Finally, exporters were offered foreign exchange retention rights to be utilized for the import of raw materials, packaging materials, and goods necessary for capacity expansion. ${ }^{14}$ There is no detailed information on the actual importance of these subsidies. Scattered data suggest that they were helpful in reducing the inward-orientation of the foreign trade policy especially after 1968, when subsidy rates were increased substantially. ${ }^{15}$ However, the subsidy system was far from having the effect of devaluation since the coverage and amount of these subsidies was highly limited and they were often adjusted to the new conditions too late. ${ }^{16}$

The above summary of the elements of the trade regime indicates that the primary concern of the foreign trade policy during the period was import substitution through import restrictions and overvalued exchange rates. It provides support for the argument that the foreign trade regime became increasingly more inward-looking over the second half of the 1960s. Although the data on the actual extent of the shift towards more inward-looking trade policies during the period are mired with measurement difficulties, there are strong indications of a gradual change in that direction. Indeed, there is a consensus among the scholars and policymakers of the period that the Turkish economy moved in the direction of more protectionism. ${ }^{17}$

The outcome of these foreign trade policy developments is presented in Table 1. As it shows, imports increased rather rapidly during the second half of the 1960s. Exports, on the other hand, remained stagnant for the first several years but started to increase slowly as a result of increased export subsidies after 1968. Trade balance was negative during the entire period, and increased from $\$ 108$ million in 1965 to \$264 million in 1969. Among invisibles, workers remittances became important during the late 1960s. During these years, the number of Turkish workers working in Western Europe increased rapidly, and their remittances financed an important part of Turkey's imports during the period. Despite the positive effect of the workers remittances, the positive balance of invisible accounts remained small compared to the deficit in trade account. The net result was chronic current account deficits during the period, which reached its apex in 1968.

During the 1960s, the current account deficits were financed by foreign credits. New official credits in the forms of programme and project credits were instrumental in paying back the principal of outstanding debt payments, and balancing the deficits in the current account. Foreign direct investment remained insignificant during the 1960s. 
Table 1. Balance of payments: 1965-70 (million US\$)

\begin{tabular}{lrrrrrr}
\hline & $\mathbf{1 9 6 5}$ & $\mathbf{1 9 6 6}$ & $\mathbf{1 9 6 7}$ & $\mathbf{1 9 6 8}$ & $\mathbf{1 9 6 9}$ & $\mathbf{1 9 7 0}$ \\
\hline Current account & & & & & & \\
$\quad$ Foreign trade & & & & & & \\
$\quad$ Imports (cif) & -572 & -718 & -685 & -764 & -801 & -948 \\
$\quad$ Exports (fob) & 464 & 490 & 523 & 496 & 537 & 588 \\
$\quad$ Trade balance & -108 & -228 & -162 & -268 & -264 & -360 \\
Invisibles & -10 & -14 & -14 & -9 & -5 & 4 \\
$\quad$ Tourism \& travel, net & -32 & -31 & -35 & -41 & -45 & -47 \\
$\quad$ Interest & -15 & -16 & -25 & -32 & -32 & -33 \\
$\quad$ Profit transfers & 70 & 115 & 93 & 107 & 141 & 273 \\
$\quad$ Workers remittances & -3 & -9 & 15 & 2 & -24 & -16 \\
$\quad$ Others, net & 10 & 45 & 34 & 27 & 35 & 181 \\
$\quad$ Invisibles balance & 20 & 19 & 14 & 10 & 8 & 8 \\
NATO infrastructure & & & & & & \\
$\quad$ \& Off-shore receipts & -78 & -164 & -114 & -231 & -221 & -171 \\
Current account balance & & & & & & \\
Capital account & & & & & & \\
Private resources & 27 & 41 & 29 & 35 & 44 & 92 \\
$\quad$ Direct inv. \& imports) & & & & & & \\
Official (project \& program) & 274 & 238 & 246 & 274 & 279 & 337 \\
$\quad$ Credit & 29 & 17 & - & - & 41 & 83 \\
TL grain imports \& grants & 330 & 296 & 275 & 309 & 364 & 512 \\
$\quad$ Gross capital inflow & -170 & -124 & -106 & -94 & -115 & -197 \\
Amortization of public debt & 160 & 172 & 169 & 215 & 249 & 315 \\
$\quad$ Net capital inflow & 82 & 8 & 55 & -16 & 28 & 144 \\
$\quad$ Overall balance & & & & & & \\
$\quad$ & & & & & & \\
\hline
\end{tabular}

Source: Ministry of Finance data as presented in World Bank, Turkey: Prospects and Problems of an Expanding Economy (Washington, DC: World Bank, 1975), p.345.

Foreign exchange crunch was an important policy issue in the late 1960s, and became more important as time progressed. A good indicator of the foreign exchange scarcity was the amount of foreign exchange transfers delayed by the Central Bank. Table 2 presents information on the amount of transfers waiting at the Central Bank and existing reserves. From February 1968 to February 1970, the amount of transfers waiting increased from $\$ 38$ million to $\$ 240$ million. It seems that the delayed transfers increased even more between February and June of 1970, as indicated by a negative increase of $\$ 50$ million in the net reserve position. The shortage of foreign exchange put increasing pressure on the policymakers to resolve the problem as early as 1968 . However, the government resolved the problem only in August 1970, when it found a window of opportunity to reform foreign trade policies.

In the late 1960s, the sources of protectionist pressures included industrialists in general, the public sector, and importers. These groups promoted an importsubstitution policy as the only way for Turkish industrialization, although their opinions varied on its precise implementation. Since the rents derived from the protectionist policies increased dramatically during the 1960s, the efforts of the members of the protectionist coalition to preserve the status quo were intensive. 
During the 1960s, protectionism from foreign competition via import controls on finished products, and less restricted import of unfinished goods (raw materials and intermediate goods) were the pillars of the import policy stand around which all industrialists could easily coalesce. As manufacturers claimed to have produced an item locally, the government moved that item onto the 'prohibited list'. ${ }^{18}$ On the issue of importing investment and intermediate goods, on the other hand, the industrialists demanded easy access to foreign markets. ${ }^{19}$ Not surprisingly, the share of consumer goods imports in total imports dropped and remained low during the 1960s while the share of raw materials and investment goods imports increased significantly. According to the SPO, the total of raw material and investment imports constituted 92 per cent of total imports in 1967, compared to 84.8 per cent in 1963. Although M. Yaşa's calculations differ, they too indicate that consumer goods imports were almost insignificant during the period (see Table 3). ${ }^{20}$ Thus, import restrictions on consumer goods provided the industrialists with a domestic market virtually shielded from international competition, while enjoying substantial access to foreign markets for their investment and raw materials needs.

The most notorious of the industrial interests in demanding protectionism and opposing any hint of import liberalization was the 'assembly industry sector', which imported parts and assembled the product in the country. The description of assembly industries by some as 'disguised imports' was not totally unfounded. These industries grew in the second half of the 1960s mainly in consumer durables. The state attempted to increase the domestic content of the products of the assembly industries.

Table 2. Waiting foreign Exchange Transfers and Reserves at the Central Bank: 02/1968 to 06/ 1970 (US\$ Millions)

\begin{tabular}{lccc}
\hline & Waiting transfers & Reserve & Net reserve \\
\hline 1968 February & 38.0 & 30.1 & -8.0 \\
1969 February & 155.0 & 27.0 & -128.0 \\
1970 February & 240.0 & 184 & -123.0 \\
1970 June & & & -173.0 \\
\hline
\end{tabular}

Source: Cumhuriyet (Istanbul daily), 3 July 1970, p.7; and Ziya Kayla, 'Para Darlı̆̆ ve Alınan Tedbirler', Cumhuriyet (Istanbul daily), 13 July 1970, p.2.

Table 3. The composition of imports: selected years (\%)

\begin{tabular}{lrrrrrrr}
\hline & \multicolumn{3}{c}{ The Third Plan } & & \multicolumn{3}{c}{ Yasa } \\
\cline { 2 - 3 } \cline { 7 - 8 } & $\mathbf{1 9 6 3}$ & $\mathbf{1 9 6 7}$ & $\mathbf{1 9 7 1}$ & & $\mathbf{1 9 6 3}$ & $\mathbf{1 9 6 7}$ & $\mathbf{1 9 7 0}$ \\
\hline Investment goods & 37.2 & 30.1 & 29.0 & & 45.8 & 47.2 & 47.1 \\
Raw materials & 47.6 & 61.9 & 61.6 & & 48.8 & 47.9 & 47.9 \\
Consumer goods & 15.2 & 8.0 & 9.4 & & 5.4 & 4.9 & 5.0 \\
Total imports & 100.0 & 100.0 & 100.0 & & 100.0 & 100.0 & 100.0 \\
\hline
\end{tabular}

Source: SPO, Yeni Strateji ve Kalkınma Planı-Üçüncü Beşs Yll: 1973-1977 (Ankara: DPT, 1973); and, Memduh Yaşa, Cumhuriyet Dönemi Türkiye Ekonomisi (Istanbul: Akbank Yayınlar1, 1980), pp.343, 362 and 374 as cited in Henri Barkey, The State and Industrialization Crisis in Turkey (Boulder, CO: Westview Press, 1990), p.65. 
The 'Assembly Industry Guidelines' were designed to substitute domestic inputs for imported inputs. Assembly industrialists often exaggerated the domestic content of their production. However, they also opposed the government regulations requiring a certain percentage of domestic content by claiming that these regulations resulted in compromised quality. Despite their argument that they saved millions of dollars of foreign exchange for the country, the import needs of the assembly industries themselves were very high and increased dramatically over the years. For example, 38 per cent of total costs in the entire manufacturing sector was spent on imports. ${ }^{21}$

Industrialists opposed devaluation in the late 1960s. Depending upon a high level of imports, which were financed by cheap foreign exchange, industrialists attributed great importance to the overvalued exchange rates. ${ }^{22}$ Industrialists argued that the state was responsible for providing the foreign exchange needed for the flow of imports. They were supportive of all undertakings of the state to obtain foreign exchange, such as foreign borrowing or inducing workers' remittances at higher exchange rates, except the devaluation of the TL. For example, when in April 1970 the World Bank officials visited Turkey's industrial chambers to solicit their views on the possibility of a devaluation decision, the industrialists adamantly opposed such a move. They asserted that 'Turkey has previously tried such a measure, and such a move would be to the detriment of producers, industrialists, consumers and investments. As in the past, a devaluation would have only a limited effect and its sole beneficiaries would be the middlemen. ${ }^{23}$ The industrialists instead argued for a system of export and tax rebates to encourage exports, as they had done prior to the 1958 reform.

Large industrialists supported integration with the European Economic Community (EEC) on the condition that 'the conditions were in accordance with Turkey's conditions'. For example, the President of the Istanbul Chamber of Industry, Ertuğrul Soysal, welcomed the signing of the agreement with the EEC on 24 July 1970 , but added that 'the most important decision favouring Turkey was the replacement of the Community's demand for the elimination of customs taxes for machinery and some raw materials imports after 8 years with a more advantageous 12 to 22 -year period' ${ }^{24}$

If taken narrowly as the state enterprises, the public sector's interests in foreign trade policy changed little since their foundation in the 1930s. They sought isolation from foreign competition and relatively unrestricted access to import markets for their raw materials and investment goods needs. At a broader level, when the public sector is taken to include state bureaucracy, the overall policy position also remained the same. The SPO, the leading economic policymaking institution, 'has never tackled the issue of how to balance foreign accounts'. ${ }^{25}$ The difference between state enterprises and the SPO seemed to be that the SPO occasionally reminded the policymakers that the public enterprises ought to be reformed to become more efficient.

One must also consider the policy positions of the intellectuals who shared common roots with the bureaucratic class and the Republican People's Party (RPP), which remained the party of the bureaucracy until the mid-1970s. During the 1960s, both stressed fear of foreign competition, export pessimism, exploitative nature of foreign trade linkages, and the necessity of planned industrialization under state tutelage. For example, one of the leaders of the RPP, Kemal Satır, stated that the Turkish industry could not compete in an open market. He continued to argue that what Turkey needed was planned industrialization under state leadership. ${ }^{26}$ 
Intellectuals with left leanings, who practically shaped public opinion during the period, argued that it was too early for Turkey to enter into the transitionary phase with the EEC. For example, G. Kazgan, argued that 'the Turkish economy will not be able to stand the competition. The advantages provided to Turkey are not as important as they appear. ${ }^{27}$

During the 1950s, importers and industrialists came together to defend protectionist foreign trade policies. However, during the 1960s, their policy positions diverged, especially in the area of import policy. The difference stemmed from the fact that during the planned period of the 1960s imports of consumer commodities, the main activity of importers, as a percentage of total imports decreased significantly. According to the Third Five Year Plan, the share of consumer goods decreased from 15.2 per cent of total imports in 1963 to 8.0 per cent in 1967. The decrease in consumer goods imports was due to increasingly protectionist import policies in the second half of the 1960s as more of these goods were produced (or assembled) in the country. As we mentioned earlier, industrialists' demands from the government to restrict the imports of domestically produced goods were met favourably. The second point of divergence between industrialists and importers during the second half of the 1960s reflected 'the turf' war between these two groups. Increasing import needs of the industrialists during the 1960s encouraged them to diversify into import activities, which led to a shrinkage of the domain of importers.

Under these tensions, importers objected to the excessive level of protectionism in foreign trade policy. Their interest did not lie with a liberal import regime, which would have lessened the level of profits from importing. They preferred a more balanced foreign trade regime, which would ensure the infusion of foreign exchange into the economy so as to finance a healthy level of imports. The most serious opposition to excessive protectionism came from the Istanbul Chamber of Commerce (ITO in Turkish acronyms) since it contained the largest concentration of importers. The Chamber's opposition centred on two threads of arguments, the first of which was that import substitution strategy emphasized industrial production at the expense of other activities. Secondly, ISI resulted in inefficiencies leading to the production of high cost and low quality domestic goods. As an extension of the latter argument, ITO's president pointed out that 'no industry which surrounded itself with protective customs barriers of the magnitude of 150 per cent could ever hope to export its output'. ${ }^{28}$ However, compared to the strictly protectionist groups (i.e. the industrialists and public sector), complaints of the importers against protectionism remained rather limited and politically ineffective.

It is also conceivable that foreign investors in Turkey had an interest in the protectionist trade policies. Almost all foreign investment activities, in the form of joint ventures with domestic import-substituting holding companies, were geared toward the Turkish domestic market. Since their products produced in Turkey were isolated from international competition, exporting was not a concern, and relatively liberal repatriation laws applied, foreign investors did not have an interest in exportoriented foreign trade policy. Since foreign investors' interests were shared and defended strongly by the Turkish holding companies, it is not necessary to link these entities directly with the politics of the trade reform. ${ }^{29}$

Groups with pro-trade preferences during the 1960s were agricultural sector, exporters, pro-trade elements within the state, and international financial suppliers. 
Yet, there were some new groups with pro-trade interests that emerged during the 1960s, such as the Turkish workers in Western Europe and the tourism industry. In addition, exporters, who exported agricultural commodities during the 1950s, started to export products of several labour-intensive, agriculture-based industrial sectors, such as food processing and textile sectors.

By 1970, the Turkish workers abroad and industrial exporters began to occupy a significant place within the structure of the Turkish economy, but they did not possess a significant level of bargaining power with the government. They too, like the other pro-trade groups, suffered from weaknesses of interest articulation and organization. The first generation of the Turkish workers abroad, who left the country in the midto-late 1960s, were connected strongly to their relatives back in Turkey, and were compelled to transfer their remittances back home regardless of the effective exchange rate. Therefore, their veto power over exchange rate policy through holding remittances did not exist during the late 1960s. The workers had not yet formed strong organizations to wield influence on the government. Their power on the government was indirect, i.e. through holding lesser or more amounts of remittances abroad, and became important only when the foreign exchange crunch intensified.

The agriculture-based industrial exports emerged after 1967. Adoption of export rebates for industrial exports played an important role in this development. Yet, the share of these exports in the total foreign exchange earnings of the country was still relatively small. It was, for example, 18 per cent in 1969 and 17 per cent in $1970 .^{30}$ Thus, the bargaining power of the agro-industry exporters for the advancement of pro-trade causes was limited. In addition, it is very likely that many of these exporters were also involved in either import or industrial production for the domestic market, which would result in compromised position on the issue of advancing pro-trade policies.

During the late 1960s, the overall interests of the pro-trade policy coalition were presented as a policy platform on the issue of Turkey's integration with the EEC. As we will discuss later, Turkey's move from 'the preparatory period' into 'the transitionary period', was on the political agenda in the late 1960s. The protrade elements considered the start of the 'transitionary period' with the EEC as a positive step for Turkey's economic development. They argued that the strengthening of the ties with the EEC would lead to increased agricultural exports, workers' remittances, tourism earnings, foreign capital inflow, and foreign aid for Turkey. But, for the industrial sectors, it was considered necessary to restructure these sectors so that they become competitive enough to capture export markets abroad. Agricultural reforms that would increase efficiency were considered to be a priority. It was also argued that the integration with the EEC would have quickened reform programs such as tax, education, and land reforms. ${ }^{31}$

However, these domestic pro-trade societal groups during the late 1960s were both organizationally and economically weaker than the protectionist societal groups discussed earlier. Their pro-trade influence on the government's foreign trade policies was minimal. Additionally, the policymaking process was controlled by the protectionist segments of the bureaucracy. However, foreign exchange shortages appeared and slowed down the economic activity in the country. The initial political effect of the shortage was a strengthening of the policymaking power of the pro-trade elements within the state. This development prepared the state policymaking process 
to overcome the foreign exchange problem more effectively by empowering technocrats with pro-reform policy tendencies. These technocrats were able to gain the confidence of the international financial institutions to open the channels of foreign credits, which was the most immediate goal under the circumstances.

During the late 1960s foreign exchange shortages led to a concentration of policymaking power within the Office of the Prime Minister and the offices of three important technocrats reporting directly to the Prime Minister. ${ }^{32}$ The formation of this 'trio' working with the Prime Minister was a result of several factors. First of all, Prime Minister Demirel had an interest in economic policymaking himself, and made all the major economic decisions since he was elected to the office in 1965. Secondly, the three technocrats had been working in great harmony, making policy coordination possible. Since 1967, Turgut Özal, the SPO Chief and Naim Talu, the Governor of the Central Bank, both under the Office of the Prime Minister, and Kemal Cantürk, General Secretary of the Treasury under the Ministry of Finance, had formed a close personal and work relationship. ${ }^{33}$ Prime Minister Demirel entrusted to this trio day-to-day management of the economy. When the foreign exchange problems appeared in the late 1960s, Demirel worked with the trio to prepare a reform package kept secret from other policymakers. The trio also handled Turkey's negotiations with the international financial organizations. Towards the end of the 1960s, there had been discussions of devaluation within and between Turkey and international financial institutions. The first IMF recommendation for devaluation during the 1960 s was made in $1966 .{ }^{34}$

By 1968, although faced with strong opposition from their peers, several economists and practitioners pointed out the negative effects of currency overvaluation and import restrictions, and urged a flexible exchange rate and gradual liberalization of foreign trade. The Prime Minister seemed to be well aware of these discussions. ${ }^{35} \mathrm{He}$ was in line with the academic and technocratic arguments made for a more realistic version of foreign trade policy. His government intended to 'reduce the bias against exports and export sectors and that, as part of the long term objective to diversify export industries, the SPO [under Turgut Özal] intensified its efforts to prepare export-oriented investment projects to be presented to the World Bank as early as $1967{ }^{36}$

Prime Minister Demirel seemed to make up his mind about the necessity of a devaluation in the aftermath of the October 1969 general elections. Demirel assigned 'the trio' to work on a reform 'package' in the summer of $1969 .{ }^{37}$ Initially, there was a hesitation on the part of the Prime Minister and his technocrats about devaluation. For example, when the RPP, as the main opposition party, brought up the claim that a new devaluation was on the way during the 1970 budget debate in the Grand National Assembly, Prime Minister Demirel offered a strong response by stating that 'A devaluation will definitely not take place. Devaluation is a sign of a weak economy. ${ }^{38}$

Despite Demirel's public statements to the contrary, the deadlock at the Central Bank due to foreign exchange transfer delays and the slowdown in the industry due to import shortages bothered him. ${ }^{39}$ Yet, the situation was not as desperate as the situation in the pre-1958 period, providing Demirel with some space for the decision on the timing of the reform. Therefore, besides the foreign exchange 
shortage itself, other factors weighed in on the reform decision. These factors included an intra-party revolt against Demirel, worsening relations with the private sector, relations with the EEC, and demands of the international financial community. As the Finance Minister Mesut Erez, in his answer to the question why the devaluation was not undertaken earlier, stated 'for a devaluation there has to be the right political and psychological conditions as well as economic ones. ${ }^{40}$ These factors are considered next.

The Justice Party (JP) came to power in 1965 with 52.9 per cent of the votes. The JP was perceived to be the party of the private sector, but it also compensated the interests of popular classes of the society, most importantly farmers. However, as the economy boomed after 1965, foreign exchange (and bank credits) became scarce for the aggressively growing private sector. Indeed, the growth rates of export earnings and foreign and domestic credits were all proportionally smaller than that of the overall economy, placing a premium on foreign exchange and credits, which remained at fixed prices. The most explosive growth during the period took place in the manufacturing sector, especially in the 'assembly industries'. This state-aided growth was resented by other segments of the private sector, such as commercial land interests, and smaller industrial establishments.

The JP was initially endorsed by large, commercial agricultural interests of Western and Southern Anatolia. By the end of the 1960s, however, the representatives of the land interests were alienated within the JP mainly by industrial interests. Combined with a personal dislike of Demirel, 41 parliamentarians voted against the 1970 budget resolution of their own party on 13 February 1970. The rebels later formed a new party named after the Democrat Party of the 1950s: 'Demokratik Parti'. One of the common policy stands of the Demokratik Parti members was the agricultural sector ignored by the JP leadership in favour of 'assembly industries', used in a rather pejorative sense. They argued that agricultural and industrial development should progress in harmony, and that the development strategy should be more balanced by including the promotion of agricultural exports. Secondly, they were furious at the JP leadership, which was considering a land reform and a tax on agricultural incomes, demanded by industrialists, civil-military bureaucracy, and the political left to transfer resources for faster industrialization. ${ }^{41}$

Demirel's timing of the reform may have been influenced by the actions of the Demokrat rebels within the JP. Worried about losing some of the rural support to the Demokrats, the government first raised support prices for agricultural goods rather drastically, making them less competitive in export markets. The devaluation that followed, however, made them more competitive compared to previous years. The Demirel government may have appeased the commercial agricultural interests via a devaluation, but further angered the industrial interests.

In the mid-1960s, the business interests were united under the JP banner. The semi-official Turkish Union of Chambers (TOBB in Turkish acronyms), the umbrella organization of the private sector, with the exception of agricultural interests, was totally under the tutelage of the JP. However, 'the discontent brewing over the party's handling of the parochial concerns [surfaced] in 1969 with the revolt at the TOBB, the heart of Demirel's constituency'. ${ }^{42}$ In May 1969, Necmettin Erbakan was elected to the TOBB leadership, defeating in the elections the incumbent supported by Prime Minister Demirel. Erbakan was highly popular 
among small-to-medium Anatolian businesses which felt increasingly alienated from the JP government due to its import and credit policies favouring assembly industries located in large cities of Western Turkey. Erbakan stated repeatedly that the comprador businessmen of the large cities, "who want to add the 21 st factory to the 20 th', 'sell their assembled truck for 140 thousand liras without any remorse'. ${ }^{43}$

The sudden challenge of Erbakan upset industrialists and large city businessmen as well as the Prime Minister. Industrialists evaluated the situation and concluded that their most serious problem was that 'the industry, unlike in other countries, does not carry sufficient clout to impose its own ideas on the government' and an organization of their own was 'necessary and vital, if they are to become an influential force in the political economy'. ${ }^{44}$ Using a legal excuse as a reason, the government refused to recognize the TOBB elections and utilized its powers to neutralize Erbakan's power in the TOBB. Among others, Demirel's tactics to discredit the new TOBB included revoking its legal authority over foreign trade and transferring it to the Ministry of Trade. This crippled the TOBB financially since at the time about a third of its income came from disbursement of import quotas, and forced the firing of most of its staff. Demirel's tactics worked and the new TOBB elections resulted in a JP dominated leadership. In exchange, the government restored the TOBB's licensing authority quickly. ${ }^{45}$

Yet industrialists were irritated by the methods of the government to replace Erbakan because the withholding of the import quotas hurt them most. As a counter-measure to their perceived vulnerability in the case of a long debacle between the Erbakan and JP supporters, industrialists attempted to ameliorate antagonisms. The industrialists came out of the TOBB struggle with the realization that "we were forced to cooperate with the party [JP] because of the delicate situation created by Erbakan. However, the day will come when the private sector will be strong enough that the Istanbul Chamber of Industry would no longer be influenced by political parties. ${ }^{46}$

By 1970, Demirel knew too well that the antagonisms within the private sector between the industrialists and others stemmed largely from the fact that the premium on foreign exchange was becoming higher as the Central Bank delayed foreign exchange transfers. He might have calculated that eliminating or reducing these rents created by overvalued exchange rates (and the scarcity of import items) could have eased the struggle within the private sector. A devaluation with import liberalization could have done just that. A devaluation could have reduced the demand for imports at the same time expanding import capacity of the economy, which could have been financed by increased export earnings, workers' remittances and foreign credits. Since the lion's share of the rents created by the import-substitution policies had been funnelled to the industrialists, a policy reform rationalizing the foreign trade area would have drawn the strongest opposition from the industrialists. But, from the perspective of the JP, the industrialists had no choice within the political system besides the JP, especially at a time when the RPP was leaning towards the left under the new leadership of Bülent Ecevit. ${ }^{47}$ The fast growing influence of the militant trade unions in the work place, and that of Marxist student organizations on university campuses also worried the industrialists.

In the summer of 1970 , the Demirel government was probably at its weakest point politically against the private sector as a whole. ${ }^{48}$ Ironically, it was also a period 
during which the government was more powerful than before vis-à-vis any particular private sector group thanks to the cleavages within the private sector. The government also had an opportunity to act independently since it was impossible to please them all at the same time. More importantly, sitting on the reform package could have made the struggles even more destructive as the foreign exchange crunch was becoming more acute. The Prime Minister used this window of opportunity to initiate the August 1970 trade reforms, and attempted to settle the grievances, especially of the industrialists, over the reforms afterwards.

The Demirel government also had foreign relations incentives to overhaul the foreign trade policy. More important of these was related to Turkey's relations with the EEC. In 1963, Turkey signed an association agreement (known as the Ankara Agreement) with the EEC, under which Turkey declared its desire to become a full member of the EEC in the future. The Agreement projected what has been commonly called a 'preparatory stage' of Turkish-EEC relations, during which Turkey would prepare its economy for the full integration by utilizing the financial resources extended by the EEC. In addition, the EEC would remove unilaterally its trade barriers with Turkey.

These principles were tied to a time schedule on 23 July 1970 in a new agreement called the 'additional protocol', which started Turkey's 'transitionary period' towards its customs union with the EEC. Under the terms of the additional protocol, the EEC would provide advantages for the 90 per cent of Turkey's agricultural exports to the Community by eliminating the tariff barriers. Furthermore, Turkish industrial exports would not face any trade barriers. There were only a few exceptions to this principle: several Turkish textile export items were under quota limitations. On the other hand, Turkey was in principle required to eliminate its tariffs on industrial sectors within the next 12 years. However, Turkey was allowed to extend this transitionary period up to 22 years for 45 per cent of its imports from the Community members if it needed to protect its weak industrial sectors. Also under the terms of the new protocol, the EEC would extend a credit line of $\$ 195$ million over the next five and a half years. ${ }^{49}$

The August 1970 measures could be considered as part of the direction Turkey was taking towards the EEC. Like the reform measures, the agreement with the EEC drew heavy criticism from certain interest groups. What was remarkable was that the positions of the interest groups towards the reform were almost identical with their positions towards the customs union with the EEC. There were claims that the EEC required a devaluation in return for the signing of the agreement. These claims were never substantiated. ${ }^{50}$ A more substantial effect of the 'additional protocol' with the EEC on the reform decision was through its provisions to provide Turkey with new export opportunities. As the Minister of Foreign Affairs, İhsan Sabri Çağlayangil, reported to the press, the negotiations with the EEC resulted in gaining access to a new market under highly advantageous conditions for industrial, agricultural, tobacco, citrus fruits, olive oil, and wine exports. ${ }^{51}$ These opportunities gave Demirel an important incentive to undertake the trade reforms since the strongest claim of the opposition to the devaluation was that Turkey, as a developing country, could not increase exports due to the protectionist policies of the developed world.

The second important factor was the pressure of the international donor institutions such as the IMF and OECD Consortium for Turkey. Although these 
pressures were not as strong as they were prior to the 1958 reform, they were not unimportant since the foreign credits were initially important for easing the foreign exchange crunch and for financing the investments provisioned under the five-year plan and annual programs. While the influence of the IMF is more detectable, those of the OECD Consortium and the EEC are not as clear.

Towards the end of July 1970, 'the trio' met Ernest Sturch, the official at the IMF's Turkish Desk in Istanbul, and gave him a letter of intent, which stated the details of the reform package and its date. When the reform program was unveiled on August 10, the IMF provided Turkey with a credit line of $\$ 950$ million, the first instalment of which was sent to the Central Bank of Turkey the next day. ${ }^{52}$ The OECD Consortium offered Turkey $\$ 97.37$ million as program credit and $\$ 39.6$ million as project credit on 23 July 1970. Turkey had asked for $\$ 140$ million for program credit and $\$ 190$ million for project credit. The press reported that the differences were due to the fact that the Consortium was trying to force the Turkish government to devalue. However, A. Krueger writes that 'it seems likely that the Consortium and its members had merely helped persuade the Prime Minister and others of the desirability of devaluation instead of making it a pre-condition of aid renewal, and that the timing was essentially a domestic political decision. ${ }^{53}$

Prior to the August reform, the press reported that one of the results of the decline in the OECD credit amounts would be an extension of the waiting period for foreign exchange transfers from the Central Bank from the current 7-8 months to a year. ${ }^{54}$ Prime Minister Demirel, in his defence of the reform decision, argued that foreign loans were available as a result. ${ }^{55}$ However, he stated that his main goal in the reform was to address the small size of export earnings. In a speech in September 1970, he stated that 'Today, our foreign exchange earnings are $\$ 840$ millions. If the total increases to $\$ 1$ billion, then we can balance our foreign accounts. I ask you [Turkish private sector] to achieve that, this has become a national goal. ${ }^{56}$ In addition, after 1968, the SPO had emphasized the promotion of non-traditional exports, and export incentives had clearly met with some success. Devaluation was certainly consonant with the emphasis on new exports, and was probably an important factor influencing the Prime Minister's thinking. ${ }^{57}$ Thus, it seems more likely that his reform decision was driven by a genuine intention of increasing foreign exchange earnings rather than fulfilling conditions to receive more foreign credits.

The 10 August 1970 reform package included devaluation of the TL, reduction in import restrictions, and additional export incentives for non-traditional exports. The core of the 1970 program was the nominal devaluation of the TL from its previous official rate of 9 TL per US dollar to 15 TL per U.S. dollar. As an exception, however, a lower rate of TL 12 per dollar was adopted for nine traditional export commodities - cotton, figs, fig cakes, hazelnuts, molasses, oil cakes, olive oil, raisins and tobacco - which constituted the majority of Turkey's exports. The government promised to gradually eliminate this temporary bias against traditional exports, which took three years. ${ }^{58}$

Although the principles of the import regime remained intact, there were several changes to lower landed cost of imports and to relax the import regime, which had become highly restrictive. First of all, the stamp duty on imports was reduced from its 
1969 level of 25 per cent to 10 per cent. It was envisaged that this tax would be abolished as soon as it became feasible. Secondly, some intermediate iron and steel products were granted full duty exemptions. Third, advance deposit requirements were lowered by 50 per cent from their 1969 range of 20 to 150 per cent with a few exceptions. The reduced rate was 45 per cent for high priority raw materials and investment goods on the liberalized lists, and 60 per cent for other goods in general. ${ }^{59}$

While the tax rebate system remained the most important component of the export promotion efforts, there were several changes in the export policy. First, the tax rebate system was simplified by replacing the old system, which with time had become very cumbersome. The new system created four export commodity lists eligible for a tax refund ranging from 15 to 40 per cent. In certain cases, exporters with less than $\$ 1$ million per year export sales would receive only up to 30 per cent. Second, the provisions for export credit and for interest rates payable by exporters were modified to increase effectiveness. A 'Foreign Exchange Equalization Fund' was established to collect the profits from the sales and purchases of exchange at different rates, and then to subsidize the interest cost of export credits and to finance development projects with an export potential. Finally, the new system allowed the allocation of more foreign exchange for the import of inputs by manufacturing exporters. ${ }^{60}$

Of interest here is the actual change that the new trade measures effected on the incentive structure of the trade regime. There is evidence that the reform measures resulted in substantial reduction in the inward bias of the trade regime (See Table 4). The ratio of premium-inclusive import EER to export EER (the most reliable measure of the bias of the trade regime towards imports) declined from 3.01 to 2.11 as a result of the 1970 reform. The decline in the bias continued at least until August 1972 , but by that time imports were still more profitable than exports by a ratio of 1.80 to $1.00 .^{61}$

By the early 1970s, the 1970 reforms proved to be the most successful foreign trade policy measures in Turkey. Turkey's trade balance deficit gradually increased during the first three years of the 1970 s, amounting to a 100 per cent increase. Since imports were artificially low at the beginning of the period, they increased by 114.7 per cent in three years. Exports, on the other hand, increased even faster - by 130 per cent between 1970 and 1973. Therefore, the overall relative change in trade imbalance must be viewed as positive, since exports showed stronger growth than imports. During the same period, workers' remittances suddenly became the most important item on the current account. It increased from \$141 million in 1969 to \$273 million in

Table 4. Bias of the trade regime before and after the 1970 reform: The ratio of premiuminclusive effective exchange rates for imports to the effective exchange rates for exports (TL per dollar)

Ratio of premium-inclusive import to export EERs

Prior to the reform 3.01

After the reform (1970) 2.11

Two years after the reform $\quad 1.80$

Source: Anne Krueger, Liberalization Attempts and Consequences (Cambridge, MA: Ballinger Publishing Company for National Bureau of Economic Research, 1978), pp.102, 105 and $108-9$. 
1970 , to $\$ 471$ million in 1971 , and to $\$ 1,183$ million in 1973. Also, Turkey's historically negative tourism and travel balance turned out positive in 1970 for the first time, and remained positive afterwards. The surge in workers' pay covered the negative trade balance for 1970 to 1972. In 1973, they even surpassed the negative trade balance leading to a current account surplus of $\$ 497$ million, which had happened in Turkey for the first time in the post-World War II period (see Table 5).

As the outcome of the reform measures suggests, the August 1970 reform was highly successful at easing the foreign exchange bottleneck and orienting the economy towards exchange earning activities. The reforms benefited the agricultural sector in general, industrial exporters, Turkish workers working abroad, and - to a lesser extent - the tourism sector. We can add that international financial institutions also benefited from the boom in Turkey's exchange earnings in the sense that they were relieved of pressures from Turkey to obtain credits beyond its borrowing capacity. On the other hand, import-substituting industrialists (assembly industries in particular), large segments of the bureaucracy and intelligentsia, and - to a lesser degree - importers all opposed the implementation and long term sustainment of the reform measures.

Table 5. Balance of payments accounts: 1969-73 (million US\$)

\begin{tabular}{lrrrrr}
\hline & $\mathbf{1 9 6 9}$ & $\mathbf{1 9 7 0}$ & $\mathbf{1 9 7 1}$ & $\mathbf{1 9 7 2}$ & $\mathbf{1 9 7 3}$ \\
\hline Current account & & & & & \\
Foreign trade & & & & & \\
$\quad$ Imports (cif) & -801 & -948 & -1171 & -1563 & -2036 \\
Exports (fob) & 537 & 588 & 677 & 885 & 1317 \\
$\quad$ Trade balance & -264 & -360 & -494 & -678 & -719 \\
Invisibles & -5 & & & & \\
$\quad$ Tourism \& travel, net & -45 & -47 & -60 & -62 & -59 \\
$\quad$ Interest & -32 & -33 & -36 & -35 & -35 \\
$\quad$ Profit transfers & 141 & 273 & 471 & 740 & 1183 \\
$\quad$ Workers remittances & -24 & -16 & -30 & -47 & 93 \\
Others, net & 35 & 181 & 366 & 640 & 1260 \\
$\quad$ Invisibles balance & 8 & 8 & 6 & 30 & 18 \\
NATO infrastructure & & & & & \\
$\quad$ O Off-shore receipts & -221 & -171 & -122 & -8 & 497 \\
Current account balance & & & & & \\
Capital account & & & & & \\
Private resources & 44 & 92 & 72 & 82 & 129 \\
$\quad$ Direct inv. \& imports) & & & & & \\
Official (project \& program) & 279 & 337 & 343 & 304 & 337 \\
$\quad$ Credit & 41 & 83 & 55 & 16 & - \\
TL grain imports \& grants & 364 & 512 & 470 & 402 & 466 \\
$\quad$ Gross capital inflow & -115 & -197 & -125 & -127 &.. \\
Amortization of public debt & 249 & 315 & 345 & 275 &.. \\
$\quad$ Net capital inflow & 28 & 144 & 223 & 267 &.. \\
Overall balance & & & & \\
\hline
\end{tabular}

Source: Ministry of Finance data, as presented in World Bank, Turkey: Prospects and Problems of an Expanding Economy (Washington, DC: World Bank, 1975), p.345. 
Six months before the August 10 reforms, in March 1970, in his discussions of the trade reform package with the Minister of Finance and 'the trio', Prime Minister Demirel seemed to be aware of the dangers lying ahead. He said in his meeting with them that 'This is a risky decision. But we have no other choice. We will take these decisions even if they are at the expense of jeopardizing the future of my political career and the party. We are not important, finding solutions to the country's problems are. ${ }^{62}$

Seven months after the 10 August reform, on 12 March 1971, the Turkish armed forces issued a pronounciamento informing Demirel that he could either resign or face a coup. Demirel resigned. The military blamed the Demirel government for being unable to cope with 'anarchy, internecine strife, and social and economic discontent'. The military sponsored a technocratic government, which obtained parliamentary 'approval' from Demirel's JP and the centrist wing of the RPP. ${ }^{63}$ The new government was headed by Nihat Erim from the centrist wing of the RPP. The technocratic government included Atilla Karaosmanoğlu, a technocrat from the World Bank, who worked on other economic reform proposals rather than foreign trade policy. His team's reform proposals drew criticism from almost all segments of the private sector. In December 1971, Karaosmanoğlu and the other ten technocrats resigned from the cabinet. Prime Minister Erim put together a second cabinet, which included Mesut Erez, Demirel's finance minister during the August 1970 reforms, as the Deputy Prime Minister. The new cabinet was comprised of ministers with closer ties to the private sector. ${ }^{64}$

After the military ousted Demirel from power, the members of 'the trio' followed different paths in their careers. Turgut Özal, the SPO Chief and the architect of the 1980 reforms, left for the World Bank. Kemal Cantürk, the Treasury's General Secretary, was assigned as the new SPO Chief. Naim Talu, the Central Bank Governor, first became the Minister of Trade in the technocratic Nihat Erim government. Later, he became the Prime Minister for six months followed by transition to democracy with the holding of national elections in $1973 .{ }^{65}$ Thus, Demirel and Özal were pushed out of the driver's seat of the economy, while other members of the reform team took important economic portfolios in the following administrations.

The military-backed governments that were in power between March 1971 and October 1973 did not totally replace the pro-trade policymakers that undertook the 1970 measures, but left them with less policymaking power. The main thrust of the initial measures remained intact, a fact that even Özal acknowledged. However, the reform lost its momentum and follow-up measures were not taken in the following years, a conclusion that we arrive at if we compare the actual policy course with what ousted Prime Minister Demirel originally set out to do. Thus, in that sense, the 1971 military intervention did interfere with the progress of the 1970 reforms. $^{66}$

Indeed, during the military governments, Demirel made public statements about economic policy, which expressed a desire to continue with the outward-orientation of the 1970 reform measures. In September 1972, his speech in Denizli province suggests that Demirel envisioned an outward-looking, at least balanced, development strategy for the country. He stated that:

We must definitely realize our efforts to develop industries competitive in international markets by giving consideration to the principle of comparative advantage. A 'Green Plan' which aims at establishing high productivity, low 
cost, ... and agriculture-based industries must be implemented with brevity. We must aim to generate a yearly income of $\$ 500$ million from our mining resources. Again, in the tourism sector, we must have an initial income goal of $\$ 500$ million per year. We must also increase the number of workers abroad from the current half a million to one million. We must transform their remittances into investment; we must not become relaxed in the export area. Our first goal in the area of land, air and sea transportation must be to generate an initial income of $\$ 250$ million per year. ${ }^{67}$

Demirel also wrote in 1973 that 'the goal is an open political system and an open economy' ${ }^{68}$ He suggested that the rural society would be gradually transformed into an industrial and service society by establishing an economic system that would encourage rational, internationally competitive establishments as well as a competitive domestic market environment. In the context of the Green Plan, he argued that agriculture must be developed and the strength of economically weak classes must be increased. Finally, he warned against the Dutch disease by emphasizing that the increase in the amount of workers' remittances must not slow down the export drive. ${ }^{69}$

These statements indicate that Demirel's policy agenda included a rather outwardlooking foreign trade policy. However, he could not implement his policy agenda since he was sidelined by the military intervention. Some years later, Demirel claimed that 'if we had managed to remain in power until 1973, we would have balanced our trade account and solved all of the country's problems' ${ }^{70}$

The August 1970 measures led to improvements in productivity and increased income from exports. Although there were other factors contributing to the boom in the agriculture sector during the period, including very favourable weather conditions, the effect of devaluation was also important. As a World Bank study reported

Without the sharp increase in production in 1971 - 12 per cent above 1970 and 17 per cent above 1969 (in constant prices) - which was again sustained in 1972, Turkey's agricultural progress during the Second Five-Year Plan [1968-1972] would actually have been quite poor. Indeed, prospects for agriculture in 1969 and 1970 did not look promising. Part of the record output in 1971 resulted from very favourable weather, and both 1971 and 1972 benefited from strong domestic and export demand. But high production during these two years also reflected sizeable increases in the use of fertilizer, mechanization and irrigation during the Second Plan. ${ }^{71}$

Table 6 presents the development of four traditional agricultural exports during the pre- and post-devaluation periods. Clearly, there were significant increases in the exports of four traditional Turkish exports after the trade policy reform. ${ }^{72}$ Cotton was the most important export crop, which showed substantial increases beginning with the 1970 crop season.

Increased demand for these commodities resulted in increased efficiency in their production. While there were various factors influencing farmers' choice of production methods, modernization in agriculture generally speeded up after the 
Table 6. Major agricultural exports: 1968-74 (millions US\$)

\begin{tabular}{lccccc}
\hline Year & Tobacco & Hazelnuts & Raisins & Cotton & Total agricultural exports \\
\hline 1968 & 94.6 & 74.1 & 22.5 & 136.2 & 388.2 \\
1969 & 81.4 & 107.7 & 22.8 & 113.6 & 385.0 \\
1970 & 78.4 & 87.0 & 20.9 & 173.2 & 429.0 \\
1971 & 86.0 & 84.4 & 21.6 & 193.0 & 480.1 \\
1972 & 130.8 & 116.5 & 30.4 & 191.3 & 579.2 \\
1973 & 132.8 & 121.7 & 58.2 & 305.8 & 831.9 \\
1974 & 204.5 & 173.2 & 53.9 & 244.0 & 851.9 \\
\hline
\end{tabular}

Source: Adopted from Erdoğan Alkin, 'Türkiye'de İhracatın Gelişmesi ve Teşvik Tedbirlerine Genel Bir Bakış', in İktisadi Araştırmalar Vakf1, Türkiye İhracatında Gerileme Sebepleri ve Buna Karşı Alınacak Tedbirler (Istanbul: IKV, 1975), pp.38-9, Tables IX and X.

reforms. For example, cotton producers in the Seyhan Region increased their use of chemical inputs and modern methods from 1970 to 1971 while the trends were mostly in the opposite direction from 1968 to $1970 .^{73}$

As in the 1950s, the agricultural sector had a stratified ownership structure, and large landowners were politically the strongest agricultural group. ${ }^{74}$ As mentioned above, the Demokratik Parti, formed by 41 deputies who seceded from the Justice Party, voiced the concerns of the large landowners during the period. They did not oppose the devaluation but were concerned by the exchange rate difference $(\mathrm{TL} 12=\$ 1$ instead of TL15 $=\$ 1)$ discriminating against agricultural exports and in favour of industrial exports. ${ }^{75}$ Overall, however, 'only the agricultural sector was spared the "adverse" impact of the reforms". ${ }^{76}$ But the debate on land reform proposals dominated the agenda of the landed interests during the period, leaving little room for articulating their foreign trade policy interests. ${ }^{77}$ Additionally, other segments of the agricultural sector lacked the necessary organization to actively support the 1970 reforms and to demand strengthening of its measures. In fact, they were probably not aware of the positive effects of the reforms on their incomes since the state support prices did not always reflect the trends of the international markets. As was hinted in Demirel's Denizli speech quoted above, the agricultural sector was the economically weak sector vis-à-vis the industrial sector. His repeated calls for creating 'Turkish citizens with a political and economic personality' seemed to refer to the ineffectiveness of the rural sector's political articulation. ${ }^{78}$

The export interests of the agricultural sector were in part promoted by the exporters of these products in the coastal areas. However, these exporters were commonly also importers, and changed the focus of their economic activity according to the incentive structure in any given period. For several years after the devaluation, their export efforts picked up. When the TL became overvalued, they again focused on their importing activities. Therefore, their commitment to exportoriented trade policy was rather weak.

One could easily argue that the numbers for the agricultural export commodities understate their real exchange earning capacity. That is a legitimate proposition given the fact that the majority of the industrial exports were agriculture-based items; the largest expansion in exports during the early 1970s was in the food 
processing and textile sectors. Exports of processed food products increased from $\$ 55$ million in 1969 to $\$ 87$ million in 1972 while exports of textiles increased from $\$ 15.9$ million to $\$ 54.8$ million in the same period (see Table 7). However, there were new areas of manufactured exports which practically opened up after the August 1970 reforms from a base close to zero, including clothing, footwear, inorganic chemical, cement, glass and glassware and metal products. ${ }^{79}$

An analysis of the composition of industrial exports shows us that export opportunities in a significant number of commodities seemed promising during the period. Yet the producers/exporters of these industrial products were still economically and politically weak given the small size of their exports. Particularly, while the interests of the exporters in the newer export areas were gaining strength, they were not significant enough in the overall economy for them to demand a 'veto' power on the foreign trade policies. Also, there was a noticeable concentration of export interests in the food processing and textile sectors, and therefore, interest articulation is expected to be present in these sectors. However, some of these exporters were possibly involved in other types of economic activities that stood to benefit from inward-looking trade policies as well, which might have compromised their pro-trade positions.

After the devaluation, workers' remittances increased dramatically. They surpassed the estimation of the Third Five Year Plan (1973-1978) prepared in 1972, which projected them at one third of their actual value. ${ }^{80}$ Increasing at an annual rate of 35 per cent between 1969 and 1973, the number of Turkish workers abroad could have become an important source of outward-oriented pressure on the government. The policymakers usually responded to these pressures by giving them preferential treatment in the import regime, such as allowing them to import certain items duty free. Workers' pressure for devaluation was not strong since they were not a coordinated interest group. Their influence was only indirect, i.e. by sending back home a smaller portion of their earnings. Therefore, their pressures provided only a weak stimulus for overall policy changes.

Table 7. Industrial exports by commodities: 1968-72 (millions US\$)

\begin{tabular}{lrrrrr}
\hline Type of commodity & $\mathbf{1 9 6 8}$ & $\mathbf{1 9 6 9}$ & $\mathbf{1 9 7 0}$ & $\mathbf{1 9 7 1}$ & $\mathbf{1 9 7 2}$ \\
\hline Food and beverages & 29.8 & 54.9 & 41.3 & 53.1 & 87.4 \\
Textiles & 8.0 & 15.9 & 25.9 & 37.5 & 54.8 \\
Wood and printing products & 2.0 & 2.1 & 2.7 & 4.9 & 4.9 \\
Hides and leather products & 0.3 & 1.0 & 4.6 & 10.6 & 21.5 \\
Chemicals & 3.2 & 6.7 & 8.7 & 9.5 & 10.7 \\
Petroleum products & 1.3 & 2.6 & 0.6 & 2.5 & 22.7 \\
Glass and ceramics & 1.0 & 0.4 & 1.0 & 2.7 & 3.7 \\
Non-ferrous metal & 16.7 & 9.0 & 11.4 & 5.7 & 11.2 \\
Metal products and machinery & 0.2 & 0.9 & 1.8 & 2.7 & 3.7 \\
Electrical machines & - & 0.1 & 0.3 & 0.6 & 0.9 \\
Others & 1.2 & 3.3 & 2.1 & 15.4 & 15.6 \\
Total industrial exports & 63.7 & 96.9 & 100.3 & 145.2 & 237.1 \\
\hline
\end{tabular}

Source: World Bank, Turkey: Prospects and Problems of an Expanding Economy (Washington, DC: World Bank, 1975), p.346. 
Reflecting the August 1970 devaluation, Turkey's tourism and travel balance showed a small surplus for the first time in recent history. Tourism earnings expanded from insignificant numbers during the 1960s into \$171 million in 1973, resulting in a positive tourism and travel balance of $\$ 78.4$ million. Tourism earnings climbed to \$193.6 million in 1974 and then remained stagnant for the next several years, losing importance as a net foreign exchange earning sector. $^{81}$

Following the reform, the tourism sector was seriously considered as potential source of foreign exchange income. Encouraged by the devaluation, several big Turkish companies, such as Koç Holding and Yaşar Holding, diversified into the tourism sector during the early 1970s. ${ }^{82}$ However, this sector did not receive the attention it deserved from the policymakers during the period. It is difficult to detect any interest group emerging from the boom of tourism during the period. Again, the new tourism companies were often arms of parent companies involved in other areas of economic activity. Significant sectoral incentives, which could have further increased tourism income and solidified outward-oriented interests, were not employed.

In the post-reform period, communication between the reformers and the international financial institutions was not as strong as it had been prior to the reform. There were several reasons for the 'freezing' of Turkey's relations with the IMF and the OECD Consortium. First of all, the 12 March 1971 military intervention led to political uncertainties in Turkey. Despite the fact that the policymakers in the constantly changing military-backed governments of the period that were receptive to a dialogue with these institutions, meaningful policy cooperation with them was impossible. Secondly, the IMF's attention was focused primarily on the crumbling international monetary system established in Bretton Woods in 1944. Thirdly, the unexpected explosion of foreign exchange earnings from exports and workers remittances increased the Central Bank reserves to an historical high level, lessening structural pressures to consult international organizations. Thus, the international institutions did not play an important role in encouraging moves towards a more outward-orientation of the Turkish economy during the first half of the 1970 s. ${ }^{83}$

The pro-trade reformers during the early 1970s were not able to solidify their reform efforts even though 'the 1970 measures were unique in their long term approach and internal consistency' ${ }^{84}$ Their lack of coalition building effort with the foreign exchange earning sectors and the international financial institutions was decisive for the reversal of the 1970 measures. Political turbulence was also a significant impediment. Although the military council had an ambivalent position towards the reform measures, they were aware of the necessity of placing technocrats with pro-trade tendencies in place to appease the international institutions. As mentioned above, the First Erim government, for example, included Atilla Karaosmanoğlu from the World Bank as the Deputy Prime Minister. However, there is a consensus among the studies of the period that by the end of 1973 the foreign trade policy of the military government had become, in aggregate terms, as inward-looking as it was in the late 1960s. ${ }^{85}$

As indicated before, the total effects of the exchange rate, import, and export policy changes in leading to more or less inward or outward orientation of trade 
policy over the years can be traced from the direction of change in the EERs. The common problem of finding premium-inclusive import EERs also exists for the post-1970 reform period. Therefore, secondary sources are utilized to show that there was a reversal of the foreign trade policy roughly by the end of 1973.

Analysts, indeed, regarded the post-1973 period as a more inward-looking foreign trade regime. As M. Celasun and D. Rodrik argue, 'an ambitious third plan (19731977) was adopted with far reaching objectives of import-substituting industrialization in capital-intensive sectors. ${ }^{86}$ In a similar vein, H. Barkey argues that in addition to exacerbating the inward-orientation of the economy, the overvalued exchange rate [after 1974] also biased investment decisions, capital utilization and product selection. The overvalued exchange rate encouraged the movement towards assembly industries which further increased the economy's dependence on imports. ${ }^{87}$ In response, the import policy became more inward-looking after 1973. B. Balassa writes about the post-1973 period:

Discrimination against the exports of manufactured goods vis-à-vis import substitution is associated with the protection of domestic sales in the form of tariffs, quota restrictions, and import licensing. Tariffs (customs duties) on manufactured goods were generally in the 30-60 per cent range in 1973, to which a customs surcharge (15 per cent of customs duty), stamp duty (9.0-9.5 per cent of the cif value) and pier duty (...) should be added. At the same time, effective rates of protection, i.e. the protection of value added in the production process, are substantially higher than nominal rates, given that various inputs, e.g. iron and steel, enter duty free.

Customs duties and other charges changed little after 1973. However, with increased foreign exchange stringency, import restrictions have come to be increasingly applied, thus raising the protection of domestic industry and increasing discrimination against exports. Changes in this situation would be necessary, lest exports do not receive adequate incentives. ${ }^{88}$

Also, A. Krueger states that 'after 1975 Turkish importers were simply unable to obtain additional foreign exchange or foreign credits, and the restrictiveness of the trade regime increased in response to increases in demand for imports. ${ }^{89}$ Thus, the 1970 reform was reversed by the mid-1970s.

It is clear that Turkish reformers missed an important opportunity in the early 1970s to transform the Turkish economy from an inward-oriented one into an outward-oriented one. What then were the factors that compromised this unusually successful trade reform package? Reformers did not, or could not, empower politically a pact of groups benefiting from the reforms through price as well as nonprice coalition building measures. Like the reformers in the late 1950s, they did not strengthen and mobilize the support of pro-trade interest groups and the international financial community to stand against the pressures of the protectionist pact. The opportunity missed in the post-1970 reform period was greater than that of the post-1958 reform period since the 1970 episode saw one of the most dramatic increases in export earnings in Turkish economic history, providing a strong case for the sustainment of the reform measures. 
As discussed earlier, the rapid rise in Turkey's foreign exchange earnings from exports, workers remittances and tourism surprised even the most optimistic observers. The abundance of foreign exchange earnings reduced the perceived saliency of the foreign exchange issue. For the first time in post-war Turkish history, the current account had a positive balance in 1973. Beside the 'Dutch disease' in the foreign exchange area, political uncertainties due to changes in the political regime captured the attention of all actors in the political arena, which subjected the trade policy to a secondary status.

Once foreign exchange became abundant, the protectionist coalition intensified its efforts to go back to the inward-oriented pre-reform period. Despite the rapid and strong response of the economy to the measures, the protectionist groups silently or openly resisted the measures and questioned at every opportunity the long term effects of the reform measures.

Most of the civil bureaucracy together with their common ally - intellectuals argued that the devaluation did not affect exports positively despite strong evidence to the contrary. Three examples of opposition or understatement of the success of the reform measures give us an impression of how the public sector management evaluated the reform measures. One is the evaluation by a Ministry of Trade official of the reform measures, which consisted of denial and export pessimism..$^{90}$ The second is that of the SPO. The SPO's 1972 Annual Programme stated that the reform measures did not reach the majority of objectives they were aimed at even though the 1970 reform package was the most successful economic policy operation during the post-war period. ${ }^{91}$ The third example concerns the attitude of intellectuals, mostly university economists, to the reform measures. Academicians who educated the bureaucrats and influenced public opinion through newspaper articles were strong supporters of the import substitution trade policy and were ideologically closed to the entertainment of the possibility of an outward-oriented or more balanced trade policy. ${ }^{92}$

In addition to the export pessimism prevalent among public sector managers and intellectuals, another important factor was the status of the public sector in the overall economic structure. As Y. Canevi suggests, in countries where public sector imports reach significant figures, a sizeable devaluation would affect the public finances most, which often leads to the postponement of devaluation. In Turkey, the share of the public sector in imports increased from 36.29 per cent in 1970 to 45.57 per cent in 1974, an important reason why the public sector opposed solidifying the reform measures, including frequent adjustments in the value of the TL. ${ }^{93}$

Industrialists exhibited the strongest opposition to the trade reform package. In an unusual manner, they protested against the Demirel government's decision. Their bitter struggle against the core of the trade reform, devaluation, can be detected from several publications of the private sector's umbrella organization, TOBB, and secondary sources. The TOBB quickly responded to the 10 August 1970 package with a report on the problems it might bring about. An analysis of the TOBB report indicates why the industrialists opposed the implementation of the trade reforms. During the post-reform period, the most important arguments of the industrial sector against the reform measures seemed to be the following: 
1. Devaluation increased the cost of industrial production by making imports more expensive;

2. Devaluation affected industrial sectors which imported capital goods more negatively, stalling industrial investment;

3. Export push was accompanied by price increases in agricultural goods which increased the cost of production in industries using agricultural inputs; and

4. The main reason of the slack in exports was the inadequate level of production, which could have been remedied by importing enough raw and intermediate materials.

The industrialists argued that the solutions to Turkey's foreign exchange problems lay with 'measures to increase productivity that should be taken immediately.' Although they were vague about what the precise measures were to increase productivity, they seemed to indicate that preferential treatment of the industrial establishments in distributing import licenses was vital to increased capacity utilization and exports. ${ }^{94}$

The strongest opposition to the reform measures came from the least competitive economic sector: the assembly industry. TOBB published a report titled Devaluation, New Taxes and Automobile Industry in 1971, presenting one of the most direct, bitter attacks on the Demirel government's economic policy. The report charged that the devaluation and the finance law passed shortly before the August 1970 measures enacting new taxes on the products of the assembly industries - were designed with the particular purpose of weakening the assembly industry. The report argued that the last two five-year development plans aimed at protecting the assembly industry and automobile sector in particular through customs protection, tax exemptions and other such measures, and the domestic content increased as a result of the pressures from the government. It further suggests that with one final step the assembly industry could have transformed itself into a 'national industry'. The report concluded that at such a critical stage, the support policies for the assembly industry were abandoned due to the effects on the government of 'one-sided and heavy' criticism of the assembly industry levelled by the left. The report's policy proposal for the government was 'to go back to the protection and development policies envisioned in the Plans and Annual Programmes for the assembly industry'. ${ }^{95}$

Since many importers were also involved in export, their preference was a combination of moderate import restrictions and export subsidies instead of a periodically adjusted exchange rate. That way, they could profit from importing since import restrictions eased and foreign exchange was available as a result of the reforms. They could also undertake export activities while they were profitable due to the devaluation and increased export subsidies. Since importing was usually easier and more profitable than exporting, importers preferred a moderately protectionist trade regime which made importing more profitable. There is strong evidence that some of the TOBB demands were shaped in part by these concerns of the importers in large coastal cities. ${ }^{96}$

This analysis of the interests and relative power of the protectionist coalition is an indication of why the 1970 reform measures were aborted within several years following their initiation. The pro-trade reformers within the state expected that successful outcomes of the measures would ensure continuation of the measures. 
When this expectation was found to be a false one, the pro-trade reformers drew lessons from the failed experience. Indeed, 'later, in 1980, Özal strongly urged that, in order to avoid some of the pitfalls of 1970, all private sector groups - whether they be industrialists, commercial or agricultural interests - be completely ignored. ... ${ }^{97}$

The lack of coalition building effort by pro-trade reformers led to the failure in forging a pro-trade policy coalition with pro-trade private sector groups and international creditors. The pro-trade societal groups remained relatively weak in terms of economic resources and political leverage compared to the protectionist private sector groups. In particular, once the pro-trade reformers were sidelined towards the second half of the 1970s, the protectionist groups held the state hostage with their demands for more and more protectionism. As H. Barkey states, 'in the parlance of the Turkish political economy, the state gave in to all demands, however contradictory they were. What kept the system going was the state's ability to mediate the different demands through the system of interest distribution. ${ }^{98}$

The reform in 1970 was triggered by a balance of payments problem that slowed down the entire economy. Pressure on the balance of payments, created for the most part by the gross overvaluation of the TL, resulted in ad hoc measures of increased protectionism, which initially raised the level of interest rents economic operators received from imports and domestic industrial production. The beneficiaries of the protectionist policies included the public sector in general through SEE monopoly rents and through the control over the private sector in terms of input prices. Bureaucrats and politicians in charge of agencies and ministries distributing import licenses and determining import restrictions enjoyed a tremendous level of arbitrary power to create patronage relations with the private sector. Therefore, they did not want to reform the foreign trade regime until the foreign exchange crunch became serious enough to halt the economy.

There was the accession of pro-trade elements within the state to important policymaking positions, a process that started at the initial stages of the economic disequilibrium. There was a gradual process of the concentration of foreign trade policymaking power within a relatively more pro-reform segment of the government and bureaucracy. Prime Minister Demirel's office was in full control of the 1970 reform. No reform initiatives came from the Ministry of Trade or Ministry of Finance although the Central Bank was involved. The main characteristic of the Prime Ministry seems to be its particular attention to where the country stands in relation to other countries, i.e. how fragile the state is vis-à-vis the outside world, and thus were more sensitive than any particular ministry to the destabilization of the country's political economy. ${ }^{99}$

In the post-reform period, the reformers did not provide the necessary leadership to forge a pro-trade policy coalition, which could have attempted to keep the fundamentals of the reform intact. While the reformers ignored domestic pro-trade groups as these groups lacked organized power and/or interest articulation, they also underestimated the utility of continued cooperation with the international financial creditors. As more foreign exchange became available as a result of the reforms undertaken, protectionist groups whose interests lay with the preservation of the original system pressured the policymakers to abort 
the reform measures with the standard arguments of infant industries, exploitative nature of foreign trade, and export pessimism. The policymakers now under the influence of the protectionist segments of the state and society found it politically convenient to go along with the demands of the most organized and articulate groups as long as the state's economic power base was not under any immediate threat.

In the post-reform period, the reformers shared the assumption that if the right economic policy measures had been taken, positive results would have come. However, developments proved that regardless of the outcomes of the economic measures the reforms were reversed for political reasons. Despite the success of the 1970 reform, opposition to it was very strong. This was partly due to the fact that protectionist interests gained strength especially during the import substitution policies of the 1960s.

Thus, Turkey missed an important opportunity in the post-reform period to become a successful outward-oriented development model such as South Korea. A. Krueger documented the loss of economic growth during the 1960s because of excessively inward-looking foreign trade policies. Again, K. Derviş and S. Robinson showed how Turkey could have achieved far superior outcomes if it followed export-oriented foreign trade policies during the 1970s. Particularly, the 1970 reform opportunity represented a great loss for the future of the Turkish political economy since the reform was extremely successful and its reversal led to the most catastrophic economic and political results in the second half of the 1970s. As H. Barkey writes, all the policymakers were supposed to do was to re-apply the 1970 measures to avoid economic and political crisis in the later years of the 1970s. ${ }^{100}$

\section{Notes}

The author gratefully acknowledges the support and assistance of Defne Günay, a graduate student at Bilkent University.

1. See for example, Merih Celasun and Dani Rodrik, 'Debt, Adjustment, and Growth: Turkey', in Jeffrey D. Sachs and Susan M. Collins (eds.), Developing Country Debt and Economic Performance: Country Studies - Indonesia, Korea, Philippines, Turkey (Chicago, IL: Chicago University Press, 1988), pp.193-212; and, Anne Krueger and Okan Aktan, Swimming against the Tide: Turkish Trade Reform in the 1980s (San Francisco, CA: ICS Press, 1992).

2. Other areas of contention in the Turkish political economy during the 1960s and 1970s included interest rate and credit policies, direct foreign investment policies, agricultural support policies, and regional inequalities in the distribution of resources. See Henri Barkey, The State and Industrialization Crisis in Turkey (Boulder, CO: Westview Press, 1990), especially pp.109-48.

3. Devlet Planlama Teskilati (DPT), Kalkinma Plani: Birinci Bes Yil (Ankara: Basbakanlik Devlet Matbaasi, 1963), pp.41-2.

4. Baran Tuncer, 'Türkiye'nin Sanayilesmesi ve Sanayi Politikalari', in Ekonomik and Sosyal Etüdler Konferans Heyeti, Dis Ticaret ve Ekonomik Gelisme (Istanbul: Ekonomik ve Sosyal Etüdler Konferans Heyeti, 1979), p.179.

5. Zeyyat Hatiboglu, Dis Ticaretimiz ve Devalüasyon (Istanbul: Hüsnütabiat Matbaasi, 1969), pp.78-9. The price increase in the United States amounted to only $6 \%$ while it reached $23 \%$ in England and France. See p.79.

6. This seemed to be consistent with the broader goal of 'deepening' import substitution in the economy. See Table 4. 
7. The Import Regime was implemented through annual import programs published annually in the Official Gazette, which was also reprinted by the TOBB.

8. However, considerable amounts of imports against the regulations passed through the customs, which were either permitted by special commissions established within the Regime or by special decrees of pardon enacted occasionally to legalize a de facto change in the composition of commodities. See Erhan Bener, 'Foreign Trade Regime of Turkey', in The Economic and Social Conference Board, Foreign Trade and Economic Development (Original in English) (Istanbul: The Economic and Social Studies Board, 1968), p.184.

9. Anne Krueger, Foreign Trade Regimes and Economic Development: Turkey (New York: Columbia University Press for the National Bureau of Economic Research, 1974), p.159.

10. Ibid., p.165.

11. Ibid., p.158.

12. Ibid., p. 165 .

13. Unrealistic registered export prices for chrome resulted in a continued loss of market for Turkish producers. See Krueger, Foreign Trade, p.189. See also pp.188-9.

14. See Erdogan Alkin, 'Türkiye'de Ihracatin Gelismesine Genel Bir Bakis', in Iktisadi Arastirmalar Vakfi (IKV) (ed.), Türkiye Ihracatinda Gerileme Sebepleri ve Buna Karsi Alinacak Tedbirler (Istanbul: IKV, 1975), pp.20-2.

15. See Alkin, 'Türkiye'de Ihracatin', p.22.

16. See Mükerrem Hiç, Türkiye'de Ihracatin Gelistirilmesi Sorunu (Istanbul: Ayyildiz Matbaasi, 1973), p.63.

17. For a sample of this literature and details of the inward-oriented foreign trade policies, see Krueger, Foreign Trade; Anne Krueger, Foreign Trade Regimes and Economic Development, Vol X: Liberalization Attempts and Consequences (New York: Ballinger for NBER, 1978), esp. pp.36 and 38; Tuncer, 'Türkiye'nin', Barkey, The State, esp. p.73; and, Tercan Baysan and Charles Blitzer, 'Turkey', in Demetris Papageorgiou, Michael Michaely, and Armeane M. Choksi (eds.), Turkish State, Turkish Society (London: Routledge, 1990), esp. pp.288-9 (Figure 2.1).

18. See Barkey, The State, p.113.

19. For a statement of the industrial sector's desire for unrestrained access to import markets, see for example the press release of Dr. Orhan Isik, the President of Ankara Industrial Chamber. Milliyet (Istanbul Daily), 12 July 1970.

20. The variation between the two sources seems to be due to differences in classification.

21. See Yalçin Küçük, Quo Vadimus - Nereye Gidiyoruz (Istanbul: Tekin Yayinevi, 1985), pp.253-7.

22. See for example, Ayse Öncü, 'Chambers of Industry in Turkey: An Inquiry into State-Industry Relations as a Distributive Domain', in Ergun Özbudun and Aydin Ulusan (eds.), The Political Economy of Income Distribution in Turkey (New York: Holmes\&Meier Publishers, Inc., 1980), pp.472-5.

23. Minutes of Istanbul Chamber of Industry's Executive Council Meetings, 15 April 1970, cited in Barkey, The State, p.119.

24. Cumhuriyet (Istanbul Daily), 24 July 1970, p.7.

25. A.hmet Kiliçbay, 'Iktisadi Durum ve Planlama Teskilati', Cumhuriyet, 22 July 1970.

26. Cumhuriyet, 27 July 1970, pp.1, 7.

27. Cumhuriyet, 24 July 1970, p.7; see also, Ilhan Selçuk, 'Amerikan Pazari mi? Avrupa Pazari mi?', Cumhuriyet, 23 July 1970, p.2.

28. Barkey, The State, p.114. See also p.113.

29. For such an attempt, see Sylvia Maxfield and James H. Nolt, 'Protectionism and the Internationalization of Capital: U.S. Sponsorship of Import Substitution Industrialization in the Philippines, Turkey and Argentina', International Studies Quarterly, Vol. 34 (1990), pp.49-81.

30. See World Bank, Turkey: Prospects and Problems of an Expanding Economy (Washington, D.C.: World Bank, 1975), p.346, Table 3.2.

31. For a statement of these points, see the interview with economist Mükerrem Hiç, Cumhuriyet, 24 July 1970 , p.7.

32. One of three technocrats, General Secretary of the Treasury, was legally reporting to the Minister of Finance, but in practice he was working more closely with the Prime Minister.

33. Yalçin Dogan describes their harmony as unprecedented in Turkish bureaucratic history. See Yalçin Dogan, IMF Kiskacinda Türkiye: 1946-1980 (Ankara: Toplum Yayinlari, 1980), p.111. 
34. Ibid.

35. An excellent forum of discussion of such issues was a conference-named Foreign Trade and Economic Development - in Istanbul in 1968 organized by the Economic and Social Conference Board. Demirel sent a rather long inaugural message to the Conference. See also, Hürriyet (Istanbul Daily), 11 August 1970, which reported that 'inflation rose and foreign trade gap increased. We came to pre-1958 conditions in 1968. Since then, we have been debating whether to devalue the TL.'

36. Baysan and Blitzer, 'Turkey', p.325.

37. See Cüneyt Arcayürek's series on the package, 'Devalüasyon Defterinin Diger Sayfalari 1', Hürriyet, 16 Aug. 1970.

38. Dogan, IMF Kiskacinda, pp.117-8.

39. 'With heightened emphasis on growth during the 1960s the foreign exchange constraint was certainly viewed as a bottleneck to growth, and reported disruptions of production resulting from transfer delays and import shortages may have influenced the Prime Minister's attitude.' Betty S. Yaser, 'Economic Aspects of Devaluation of the Turkish Lira of August 10, 1972', AID Discussion Paper No.5, (Ankara), April 1972, p.2, cited in Krueger, Foreign Trade, p.312.

40. Hürriyet, 11 Aug. 1970.

41. See Ismail Cem, Tarih Açisindan 12 Mart (Istanbul: Cem Yayinevi, no date), pp.355-64.

42. Barkey, The State, p.150.

43. Ismail Cem, '1969 Seçim Sonuçlari ve Türkiye Gerçekleri', Milliyet (Istanbul Daily), 17 Oct. 1970.

44. Minutes, 20 November 1968, and Minutes, 17 November 1973, both cited in Barkey, The State, p. 151 .

45. See Robert Bianchi, Interest Groups and Political Development in Turkey (Princeton, NJ: Princeton University Press, 1984), pp.256-7.

46. Minutes, 21 January 1970, cited in Barkey, The State, p.152.

47. Ismet Inönü, the President of the country from 1938 to 1950, was still the leader of the RPP. But Ecevit as the party's general secretary was the de facto leader of the RPP due to Inönü's advanced age. Whereas Inönü was a centrist politician, Ecevit emerged as the leader of the left-of-center within the party. Ecevit became the official leader of the party later in 1972.

48. Ismail Cem suggested that all the indicators of the period point towards a weakening in Demirel's power base. See Cem, Tarih Açisindan, p.364.

49. Cumhuriyet, 24 July 1970, p.7.

50. The Minister of Finance, Mesut Erez, denied these claims, and stated that 'we took these decisions out of our belief that they are beneficial for our economy. It is impossible to link the devaluation with the foreign credits, since we obtained the credits for this year before the devaluation.' Hürriyet, 11 Aug. 1970, p.9.

51. Tercüman (Istanbul Daily), 29 July 1970, p.1.

52. Dogan, IMF Kiskacinda, pp.120, 123.

53. Anne Krueger and Vernon Ruttan, 'Turkey' in Anne Krueger, Constantine Michalopoulos, Vernon W. Ruttan (eds.) Aid and Development (Baltimore: Johns Hopkins University Press, 1989), p.312.

54. Cumhuriyet, 24 July 1970, pp.1, 7.

55. Krueger and Ruttan, 'Turkey', p.312.

56. Tercüman, 16 Sep. 1970, p.7.

57. Yaser, 'Economic Aspects', p.2.

58. Since June 1961, the exchange rate became gradually less unitary as subsidies and taxes were put into effect. By August 1970, the commodity exchange rate was still TL 9 per dollar while the workers' remittances and tourist buying rates were TL 12 per dollar and the tourist selling rate was TL 13.5 per dollar. The devaluation equalized these three rates de facto at TL 14.85 per dollar buying rate and TL 15 per dollar selling rate. See OECD, Economic Surveys: Turkey - 1970 (Paris: OECD, 1970), p.23; and Krueger and Ruttan, 'Turkey', pp.313-4.

59. See OECD, Economic Surveys: Turkey - 1970, p.25; Baysan and Blitzer, 'Turkey', p.330; and, Krueger and Ruttan, 'Turkey', p.314.

60. See OECD, Economic Survey: Turkey - 1970, p.25; Krueger and Ruttan, 'Turkey', pp.314-5; and, Baysan and Blitzer, 'Turkey', p.330. There were some other measures in the Aug. 1970 reform package that aimed at maintaining internal stability of the economy. However, there were a few related measures taken prior to the reform as well. The stabilization measures included increases in some indirect tax rates and imposition of new taxes, changes in domestic pricing policies, and slight 
changes in the structure of interest rate policy. For our present purposes, we can skip the details of these policy changes.

61. For these data, see Krueger, Liberalization Attempts.

62. Dogan, IMF Kiskacinda, p.119.

63. There have been many accounts of the 1971 pronounciamento. It is generally agreed that it was a counter-coup of the high command against a coup being planned by the junior, more radical military officials in cooperation with progressive intellectuals who advocated social and economic reforms to deepen Atatürk's revolutions. The high command initially appeased the junior officials with its reformist rhetoric, but quickly turned authoritarian, abandoned the reform rhetoric and purged the radicals from the armed forces. Another explanation is that the military suppression addressed the worries of the bourgeoisie about the rising left in the forms of militant trade unionism, and left-wing intellectual and student movements. Still another explanation is that the military pressure was applied to resolve the internal struggles of the private sector in favor of industrialists. For our purposes, we will only discuss the foreign trade policy implications of the military-backed governments between 1971 and 1973.

64. See Cem, Tarih Açisindan, pp.454-5.

65. Dogan, IMF Kiskacinda, p.122.

66. For more on these, see Emin Çölasan, 24 Ocak - Bir Dönemin Perde Arkasi (Istanbul: Milliyet Yayinlari, 1984), 19th Edition, pp.113-5; and, Barkey, The State, p.156.

67. Süleyman Demirel, 1971 Buhrani ve Aydinliga Dogru (Ankara: Dogus Matbaasi, 1973), pp.157-8. With the Green Plan, Demirel suggests a separate plan for the agricultural sector inserted into the five year development plans. The Green Plan would, among other things, encourage the production of crops with favorable domestic and international demand conditions. See his speech in Konya province on 15 October 1970, printed in Demirel, 1971 Buhrani, pp.287-90.

68. Demirel, 1971 Buhrani, p.324.

69. Ibid., pp.324-5 and 326-7.

70. Cüneyt Arcayürek, Demirel Dönemi - 12 Mart Darbesi: 1965-1971 (Ankara: Bilgi Yayinevi, 1985), p.324.

71. World Bank, Turkey: Prospects, p.182.

72. In fact, these numbers understate the importance of these crops among the exports of the country since agriculture-based 'industrial' exports, which use these crops as inputs of production, also increased during the period.

73. World Bank, Turkey: Prospects, p.208.

74. 'By 1970 about 4,000 farm units with holdings of 1,000 hectares or more were at one end of the spectrum. At the other end were 800,000 farm units with one hectare or less and another 600,000 units with between one and two hectares. Nearly half of all farms fall in these latter categories but accounted for only 11 percent of the land covered by the 1970 census sample.' World Bank, Turkey: Prospects, p.213.

75. Interview with an ex-Demokratik deputy in the Parliament, Ankara, Jan. 1994.

76. Barkey, The State, p.155.

77. Land reform was one of the explosive political issues of the late 1960s and early 1970s. The second half of the 1960s, credit-hungry industrialists joined the intellectuals and technocrats of the SPO in demanding the land reform and taxation as a way of resource transfer from the agricultural sector. The JP flirted with the idea, alienating some of its constituents (later Demokrats). Under the technocratic Erim government, the Deputy Prime Minister Atilla Karaosmanoglu prepared a land reform proposal, but it was never voted into law. There were a total of five land reform proposals floated around between 1969 and 1972. See for example, Yalçin Küçük, Planlama Kalkinma ve Türkiye (Istanbul: Tekin Yayinevi, 1978), pp.259-61.

78. See Demirel, 1971 Buhrani, p.325.

79. See Kemal Dervis and Sherman Robinson, Foreign Exchange Gap, Growth and Industrial Strategy in Turkey: 1973-1983 (Washington, DC: World Bank, 1978), p.41.

80. See DPT, Üçüncü Bes Yil - Yeni Strateji ve Kalkinma Plani (Ankara: DPT, 1972), p.190.

81. See DPT, Dördüncü Bes Yillik Kalkinma Plani, 1979-1983 (Ankara: DPT, 1978), p.67.

82. See Dogan Avcioglu, Türkiye’nin Düzeni: Dün, Bugün, Yarin (Ankara: Bilgi Yayinevi, 1969), p.1141.

83. See Dogan, IMF Kiskacinda, pp.123-7.

84. Barkey, The State, p.154. 
85. For this, see Dervis and Robinson, Foreign Exchange, p.41; Bela Balassa, The Newly Industrializing Countries in the World Economy (New York: Pergamon Press, 1981). pp.315-6; Celasun and Rodrik, 'Debt, Adjustment, and Growth', p.622; Barkey, The State, p.96;. See also, Asaf Savas Akat, Alternatif Büyüme Stratejisi : İktisat Politikası Yazıları (Istanbul : İletişim, 1983); Korkut Boratav, Türkiye Iktisat Tarihi, 1908-1985 (Istanbul: Gerçek Yayinlari, 1993).

86. Celasun and Rodrik, 'Turkey', p.622.

87. Barkey, The State, p.96.

88. Balassa, The Newly Industrializing, pp.315-6. See also, Boratav, Türkiye Iktisat; Akat, Alternatif Büyüme.

89. Anne Krueger and Okan Aktan, Swimming against the Tide: Turkish Trade Reform in the 1980s (San Francisco, CA: ICS Press, 1992), p.28.

90. D. Togay, Counselor to the General Secretariat of the Foreign Trade under the Ministry of Trade, suggested in May 1974 that 'As known, there was no contribution of the 1970 devaluation to increase our exports. ... The devaluation improved the current account balance by speeding up the import of workers' remittances.' D. Togay, 'Ihracatin Yapisi ve Özellikleri', in IGEME, Sanayiimizin ve Ihracatimizin Gelisme Yönleri Symposiumu - Ankara, 20-25 Mayis 1974 (Ankara: IGEME, 1974), p.48.

91. DPT, 1972 Yili Programi (Ankara: DPT, 1972), p.11.

92. For example, D. Togay refers to a book by Necdet Serin in his concluding sentence to quota that 'So long as the structure of the Turkish economy continues to be the same as it is today, devaluation cannot be a viable solution to increase foreign exchange earnings from exports.' Necdet Serin was an economics professor from the Faculty of Political Science of Ankara University, which educated the vast majority of Turkey's bureaucrats until the early 1980s. See Togay, Ihracatin Yapisi, p. 48. See also Necdet Serin, Kalkinma Ve Dis Ticaret: Az Gelismis Ülkeler ve Türkiye Yönünden (Ankara: Ankara Üniversitesi Siyasal Bilgiler Fakültesi, 1972), p.239. Despite unprecedented pluralism on political issues, the consensus of the intellectuals on economic policy issues remained remarkably strong and unquestioned. For an elaboration of this puzzling unity of economic ideology, see Akat, Alternatif Büyüme; and, Zeyyat Hatiboglu, Bilinmeyen Yönleriyle Türkiye Ekonomisi (Istanbul: Lebib Yalkin Yayinlari, 1995).

93. Y. Canevi, Mini Devalüasyon (Ankara: Ayyildiz Matbaasi for Türkiye Ekonomi Kurumu, 1978), p.29.

94. TOBB, Para Ayarlamasinin Getirdigi Ekonomik Sorunlar ve Kararlarla Ilgili Görüslerimiz ve Tekliflerimiz (Ankara: TOBB, 1970), pp.15-6.

95. TOBB, Devalüasyon - Yeni Vergiler ve Otomotiv Sanayi (Ankara: TOBB, 1971), p.6. Also see, pp.4-38.

96. See for example, TOBB, Para Ayarlamasinin, p.11. The TOBB report stated that 'it had suggested to the government that by increasing productivity in agricultural and industrial production, promoting exports with sufficient subsidies and raising foreign exchange income from invisibles, the exchange value of the TL can be enhanced and there would be no reason to resort to devaluation.'

97. Barkey, The State, p.166. In reality, this statement referred mostly to the industrialists and importers of 1970.

98. Barkey, The State, p.168.

99. In Turkey, the Prime Minister's Office has had the strongest incentive to fight against the weakening of the state's economic power base. Indeed, the military coups of 1960, 1971 and 1980 all blamed the ills of the country's political economy on the Prime Ministers rather than the Presidents. The coup makers also legitimized their actions by arguing that the state was about to collapse before they intervened.

100. Krueger and Ruttan, 'Turkey'; Dervis and Robinson, The Foreign Exchange; and Barkey, The State, especially p.168. 